\title{
A REFORMA SINDICAL, ENTRE O CONSENSO E O DISSENSO
}

\author{
Márcio Túlio Viana*
}

\section{INTRODUÇÃO ${ }^{1}$}

Diziam os antigos chineses que tudo tem o seu contrário: o bom e o mau, o dia e a noite, a terra e a água... Às vezes, o contrário de uma coisa pode estar até dentro dela como as duas faces de uma mesma moeda.

Tome-se como exemplo a palavra "trabalho". Ela deriva do latim tripalium, que todos descrevem como um antigo instrumento de tortura, mas alguns também traduzem como uma máquina de debulhar milho ou uma espécie de arado. Assim, numa

* Professor nas Faculdades de direito da UFMG e da PUC-Minas. Representante da ANAMATRA na Plenária do FNT. Membro do Instituto Brasileiro de Direito Social Cesarino Júnior.

1 Alguns trechos desta "Introdução" foram extraídos de outro artigo do mesmo autor. mesma palavra, colheita e perda, prazer e dor, vida e morte.

Aliás, a própria Bíblia mostra essa dualidade. Quando Adão comeu a maçã, foi condenado a "cavar o pão com o suor do seu rosto". Mas esse suor, além de um meio de expiar a sua culpa, era o modo de reconduzi-lo à salvação. ${ }^{2}$ Assim, ainda uma vez, suor e pão, pena e paz, céu e inferno.

Essa dualidade reaparece com o capitalismo, que divide os homens em possuidores e despossuídos dos meios de produção. A força de trabalho torna-se, então, mercadoria; e o trabalhador-mercador de si próprio - "perde a sua vida para ganhá-la”, como escreveu alguém, talvez Marx.

2 A observação é da colega Alice Monteiro de Barros. 
Mas eis que surge ainda uma outra contradição, também ligada ao trabalho, ou mais precisamente à fábrica. Para controlar os trabalhadores, e racionalizar a produção, o capitalista os reúne num mesmo ambiente, sujeitando-os aos mesmos sofrimentos. Nasce então a resistência operária e - com ela - o Direito do Trabalho.

É interessante notar como essa contradição da fábrica se refletiu no próprio direito, que passou a traduzir não apenas o poder dos oprimidos, mas a aceitação interessada dos opressores. ${ }^{3}$ De fato, quanto mais se consolidava, mais o Direito do Trabalho era usado para estabilizar e reproduzir o sistema não só o legitimando, mas aumentando o poder de compra das pessoas, e assim realimentando o ciclo. Essa realidade se acentuou nos chamados "anos de ouro" do capitalismo, entre o segundo Pós-Guerra e o fim dos anos 60.

Hoje, algumas dessas contradições se resolvem, enquanto outras afloram. A fábrica já não precisa reunir para produzir - e desse modo vai inviabilizando a resistência coletiva. Ao mesmo tempo, porém, a sociedade civil começa a se reorganizar em outros níveis, como são exemplo os movimentos populares, as associações de bairro e a maioria das ONGs.

Essas ambigüidades também se instalam nas aspirações do movimento sindical. Assim é, por exemplo, que a liberdade completa, que sempre foi uma de suas bandeiras históricas, agora é vista como um risco. Mas esse mesmo risco, ou essa mesma

3 Na lição de Tarso Genro, ele "carrega em todas as épocas o aprendizado dos dominadores e, ao mesmo tempo, os germens da resistência dos dominados". (Contribuição à Crítica do Direito Coletivo do Trabalho, LTr, S. Paulo, 1988, passim). fragilidade, acaba por induzi-lo a concentrar poder nas cúpulas, solução que também pode se tornar um problema.

É nesse contexto de incertezas que o Fórum Nacional do Trabalho tenta construir um novo modelo de relações entre o trabalho e o capital. Os debates se iniciaram pela questão sindical, em meados de 2003. Agora, surgem as primeiras conclusões, em forma de consensos - que mais tarde serão transformados em projetos de lei e de emendas constitucionais.

A Associação Nacional dos Magistrados da Justiça do Trabalho (ANAMATRA) não teve acesso direto aos debates. ${ }^{4}$ Por isso, criou uma comissão, ${ }^{5}$ que recolheu propostas de várias associações regionais, discutiu múltiplas possibilidades e alinhavou os pontos principais de sua própria idéia de reforma.

Como o Leitor poderá ver, as conclusões do Fórum nem sempre coincidem com as dos juízes, que são também as do autor deste trabalho. Naturalmente, isso não significa, necessariamente, que a razão esteja conosco mas talvez aponte para a necessidade de um aprofundamento das discussões. É o que tentaremos iniciar aqui, a partir de um breve diagnóstico da questão sindical.

\section{O SINDICATO, NUMA PERSPECTIVA LOCAL}

O movimento sindical está em crise. Quais as razões desse fenômeno?

4 Participou somente da Plenária, que se reuniu apenas para homologar o consenso já firmado.

5 Formada pelos juízes Jorge Luiz Souto Maior, José Augusto Rodrigues Pinto, José Eduardo de Resende Chaves Júnior, José Nilton Pandelot, Maurício Godinho Delgado, Reginaldo Melhado e pelo autor destas páginas. 
Numa perspectiva local, tomando apenas a realidade brasileira, o sindicato é frágil porque a lei que o regula também o reprime impedindo que possa se organizar de forma democrática e plural.

Mas a crise de nossos sindicatos se explica também por outros fatores, dentre os quais a ANAMATRA cita:

a) o poder normativo da Justiça do Trabalho, que inibe as suas ações e lhe subtrai responsabilidades;

b) a contribuição sindical obrigatória, que lhe permite existir mesmo quando não tem a menor representatividade - o que acaba desgastando a sua imagem;

c) as restrições ao direito de greve, não só as advindas por meio da lei ordinária, mas em descompasso com a Constituição, como as decorrentes do poder normativo, por ela previsto;

d) a falta de repressão efetiva aos atos anti-sindicais;

e) a ausência de organização nos locais de trabalho;

f) o distanciamento entre as bases e as cúpulas;

g) o distanciamento entre as próprias bases e os outros segmentos sociais;

h) o não reconhecimento formal das centrais como entidades sindicais;

i) a impossibilidade de contratos coletivos em níveis maiores;

j) a quase absoluta falta de proteção ao emprego dos nossos trabalhadores, que os faz temer a ação sindical e - aumentando o turn over - não só os desaloja constantemente de seu núcleo profissional, como também os induz à concorrência, destruindo pouco a pouco o sentimento de solidariedade.

\section{O SINDICATO, NUMA PERSPECTIVA} GLOBAL

Numa perspectiva global, a crise do sindicato começa pela própria globalização, passa pela reestruturação produtiva e termina na ideologia neoliberal, que traz de volta, com ares de novo, um velho discurso.

Em verdade, é o próprio trabalho humano que se desvaloriza, o que acaba também desvalorizando o Direito, a Justiça e todos os atores e instituições que tentam de algum modo protegê-lo.

Nasce a doutrina da flexibilização, que se concretiza, sobretudo:

a) pela retirada formal de direitos;

b) pela perda crescente de sua efetividade;

c) pela leitura às avessas do princípio da proteção; ${ }^{6}$

d) pela transformação gradativa de normas de ordem pública em regras disponíveis.

Do ponto de vista econômico, o sindicato sofre os efeitos de um novo modo de organizar a produção, que, pouco a pouco:

- transforma a grande fábrica - onde a solidariedade fermentava - numa empresa quase deserta, ou - no limite - em simples gerenciadora de uma vasta rede, que envolve tanto a economia formal como a informal;

- por isso mesmo, quebra em pedaços o coletivo operário, não só em termos físicos como psicológicos;

6 O discurso - implícito ou explícito - é no sentido de que o trabalhador está "cheio de direitos", o que inviabiliza a fonte de trabalho. Assim, o melhor meio de protegê-lo... é desprotegê-lo. A propósito, cf. o nosso artigo "A proteção social do trabalhador no mundo globalizado", Revista LTr, S. Paulo, 63-07, p. 885-896. 
- usa a automação não para criar tempo livre, mas para libertar-se, de forma crescente, da necessidade de mão-de-obra;

- transforma parte dos trabalhadores que restam em autônomos, cooperados e estagiários, alguns reais e outros falsos, mas todos desprotegidos, e cujos interesses não convergem - mas concorrem - com os dos empregados formais;

- troca os que permanecem empregados por outros - especialmente jovens e mulheres sem a mesma tradição de luta, e por meio de contratos precários;

- transforma a empresa de imóvel em móvel, ${ }^{7}$ permitindo-lhe sediar-se onde os sindicatos são mais frágeis;

- aumenta, por isso mesmo, o poder de barganha da empresa, que assim pode ameaçar deslocar-se para outras paragens, numa espécie de lock-out disfarçado;

- põe em crise, também por isso, a negociação coletiva, invertendo as posições dos atores (o sindicato profissional se defende, o econômico ataca) e, na prática, inviabilizando novas conquistas dos trabalhadores;

- oferece ao sindicato, como espaço residual de manobra, a possibilidade de negociar com os governos e as grandes corporações o próprio processo de precarização, jogando com a perspectiva teórica de reduzi-la, mas ajudando na prática a legitimá-la;

- por tudo isso, desgasta - e vira pelo avesso - a imagem e os próprios conceitos de sindicato e de convenção coletiva;

- semeia a instabilidade e - com ela o medo;

- semeia o individualismo e - com ele a cooptação;
- transforma a empresa em centro (re)produtor de ideologia, reforçada pela cooptação e pelo medo;

- acentua o poder diretivo, senão de direito, pelo menos de fato, fazendo do empregador não só o detentor do contrato, ${ }^{8}$ mas o primeiro juiz do empregado, quando este não se coloca no seu devido lugar. ${ }^{9}$

\section{O SINDICATO, EM SUA PRÓPRIA PERSPECTIVA}

Como o próprio sindicato está se vendo? Até recentemente, a maior parte do sindicalismo brasileiro não tinha uma percepção crítica do que acontecia no mundo. Via-se apenas refém de um passado corporativista e projetava um futuro exatamente ao contrário.

Nessa perspectiva, todos os problemas se resumiriam na herança de Vargas - a unicidade, o "imposto", o poder normativo, a organização por categorias. Acabando-se com isso, tudo seriam flores.

Esse modo de pensar tem até hoje a simpatia dos meios mais conservadores, inclusive a mídia. E não é por acaso. Ao reduzir a crise a um fenômeno local e circunstancial, afasta as atenções de sua dimensão também global e estrutural.

Com o passar do tempo, porém, o sindicalismo parece ir percebendo que os seus problemas têm raiz bem mais profunda. Não se resumem à famosa Carta del Lavoro. Por isso, não dependem simplesmente - nem mesmo principalmente - da revogação de alguns artigos de lei.

\footnotetext{
8 A frase é de Ribeiro de Vilhena.

9 Aproveitando uma colocação de Fiori.
} 
A propósito, aliás, não custa notar que o próprio modelo corporativo já não é o que era. $\mathrm{O}$ contexto mudou - alterando a função e a importância de cada uma das peças da engrenagem. Por isso, não se pode analisá-lo, hoje, como se ainda estivéssemos no tempo de Vargas.

Numa comparação bem singela, é mais ou menos o que acontece com as reações químicas. Como escrevemos certa vez,

tomemos como exemplo uma reação conhecida: a água. Como sabemos, ela é o resultado da união de duas moléculas de hidrogênio e uma de oxigênio. Pois bem. Se trocarmos o oxigênio pelo enxofre, o resultado será ácido sulfídrico: uma substância pastosa, com um cheiro horrível, quase o oposto da água. Conclusão: às vezes, basta que um dos elementos se altere, para que toda a reação se modifique.

Ora: o modelo corporativo exigia vários ingredientes, usados em conjunto. $\mathrm{O}$ objetivo era controlar o sindicato, a fim de que o próprio Estado absorvesse a luta de classes. Desde 1988, porém, alguns dos ingredientes não mais participam da receita, exatamente porque não se persegue o mesmo fim. O Estado já não pode, por exemplo, intervir ou interferir na vida sindical. Por isso, o resultado da reação pode ser diferente.

Mas voltemos às nossas moléculas de hidrogênio e oxigênio. Se, ao invés de trocarmos uma delas, simplesmente as aquecermos, o resultado será um gás; se, ao contrário, as esfriarmos, obteremos água ou mesmo gelo. Isso nos mostra que a simples ação do ambiente pode alterar radicalmente $o$ resultado, mesmo quando os elementos da reação permanecem os mesmos.

Pois bem. Há dez ou vinte anos, qual era o ambiente em que se inseria a ação sindical? A grande empresa era vertical. Dominava, de alto a baixo, todas as etapas de produção, fabricando em massa, para um consumo de massa. Para isso utilizava trabalhadores também em massa, com tarefas fragmentadas, repetidas, e ao mesmo tempo homogêneas.

Esses grandes contingentes de operários, trabalhando nos mesmos locais, em jornadas plenas e por anos a fio, acentuavam aquela velha contradição do sistema: a de ter de reuni-los em volta da máquina e não poder evitar que eles próprios se unissem. Além de carros e sabonetes, a fábrica produzia, assim, o seu próprio demônio.

A esse modo de ser da fábrica correspondia um modo de ser do sindicato. Também ele era grande, homogêneo, verticalizado. O pleno emprego se refletia no associativismo pleno. E, para completar, também o Estado era forte, grande, interventor.

Hoje, esse modelo está em crise. Para manter as taxas de dominação e lucro, a empresa tenta se enxugar, e para isso se automatiza, se reorganiza, se terciariza e - especialmente terceiriza. Graças aos novos recursos, como a informática, ela se parte em pedaços, através das parceiras, sobre as quais conserva uma invisível relação de domínio.

Os resultados são basicamente três: a produtividade aumenta, os custos se reduzem e a resistência operária - tanto em nível individual, como na esfera coletiva - passa a ser coisa do passado. O próprio sindicato, símbolo e expressão dessa resistência, vive a maior de suas crises. ${ }^{10}$

Como dizíamos, o ambiente mudou, o que altera o resultado da reação. Assim, o sonho de uma alteração radical no modelo pode e deve ser dosado com uma pitada de realidade. E o sindicalismo vai se convencendo disso.

Em outras palavras, a principal razão da fragilidade do movimento sindical não é a "herança de Vargas", mas a nova forma de

10 "O direito, a química e a realidade sindical", Revista do TRT da $3^{\text {a }}$. Região, n. 59, B. Horizonte, 1999, p. 49-52 
acumulação capitalista. É a estrutura, bem mais que a circunstância.

No limite, o novo modelo econômico é incompativel com o sindicato, ou pelo menos com a forma de sindicato que o mundo tem conhecido até hoje. E é exatamente por isso que alguns autores já não falam apenas em crise, mas em declínio do sindicalismo. ${ }^{11}$

Com efeito: ao externalizar os custos, a empresa divide já não apenas cada empregado, mas a própria classe trabalhadora. E é nesse ponto, mais do que em qualquer outro, que reside a grande arma do novo modelo: ele resolve a contradição da fábrica como local de trabalho e, ao mesmo tempo, de fermentação coletiva.

Por outro lado, os sindicatos - ou mais precisamente as centrais - parecem estar assumindo, definitivamente, o papel de atores de um novo modelo de negociação, envolvendo os empregadores e o Estado. Eé também este o olhar do Fórum, mesmo porque ele próprio já é a primeira grande experiência nesse sentido.

O problema é que o Estado, como dizíamos, tem poucas possibilidades de se tornar o fiel da balança. Ele próprio deve prestar contas a outros tantos atores - das multinacionais aos organismos financeiros internacionais - que o pressionam fortemente na direção dos interesses do capital.

Desse modo, o papel desse "Novo Sindicalismo" às avessas seria apenas o de tentar reduzir o ímpeto da onda flexibilizadora,

\footnotetext{
${ }^{11}$ É o caso, por exemplo, de Alain Bihr.
}

o que sem dúvida é importante; mas ao preço de legitimar - e com isso reforçar - tudo o que vier a ser flexibilizado com a sua participação. Em verdade, estará legitimando o próprio modelo e a ideologia que o acompanha.

E como o sindicato vai-se tornando mais de resposta que de ataque, a sua importância, maior ou menor, será medida pela sua intervenção, também maior ou menor, em defesa de direitos residuais. E isso poderá levá-lo a aceitar a transformação gradual de normas de ordem pública em regras disponíveis, exatamente para que - num segundo momento - possa tentar negociá-las de maneira favorável aos trabalhadores. Ou seja: na falta de um espaço onde possa negociar para cima, o sindicato ajuda a criar artificialmente um novo espaço - para baixo onde possa se movimentar.

Se essa perspectiva se confirmar, o sindicato estará atingindo o ápice de um longo processo de institucionalização, cujas bases foram construídas no início do século XX. Mais uma vez se tornará uma peça essencial ao sistema. Mas de um modo bem diferente ao dos "anos gloriosos" do capitalismo, quando realimentava o ciclo produtivo, mas aumentando o poder de compra (e, portanto, as condições de vida) dos trabalhadores.

É verdade que, já naquela época, o sindicato havia abandonado a luta contra o sistema; mas o fato é que o sistema se tornara permeável às suas reivindicações imediatas. Hoje, ao contrário, o capital quer retomar o terreno perdido. E isso inverte o papel de cada uma de suas peças, dentre as quais o próprio sindicato e a negociação coletiva. 


\section{SÍNTESE DOS PRINCIPAIS CONSENSOS DO FÓRUM}

\subsection{Quanto à organização sindical}

Os sindicatos serão organizados segundo o ramo de atividade preponderante das empresas ou das unidades produtivas de sua base de representação. Com isso, desaparecem os sindicatos de categorias diferenciadas e profissionais liberais. A base mínima continuará correspondendo a um município.

Mas essas regras se flexibilizam em relação aos atuais sindicatos, bem como aos que se constituírem até a véspera da nova lei. Para eles, haverá uma espécie de direito adquirido. Poderão continuar como estão, desde que sejam representativos. Mas se houver um sindicato no ramo da atividade econômica, os trabalhadores poderão preferi-lo.

Outro ponto importante diz respeito ao pluralismo. Numa mesma base, poderá haver mais de um sindicato. Mas essa regra também não será aplicada aos sindicatos existentes até antes da lei, desde que optem, em assembléia, pelo monopólio de representação.

E mesmo a última hipótese é flexível. Se, no futuro, um grupo de trabalhadores quiser criar um novo sindicato, basta ganhar a assembléia e mudar as regras do jogo embora, na prática, isso deva ser difícil. E pode ainda acontecer que, no futuro, um outro sindicato se organize, criando uma nova base de representação.

A exclusividade também poderá cair se o sindicato não continuar sendo representativo. Por fim, o sindicato terá de ter estatutos democráticos, cujos parâmetros serão fixados pelo Conselho Nacional de Relações de Trabalho. A intenção é evitar que o processo eleitoral dos sindicatos continue manipulado por seus dirigentes, o que acontece hoje, com freqüência.

Assim, como se percebe, a representatividade é um dos pontos-chave do novo sistema. Para ser criado e se manter vivo, o sindicato não filiado a uma central ou confederação deve ter um quadro de sócios igual ao superior a $20 \%$ dos "trabalhadores empregados" em sua base de representação (o que exclui os aposentados).

Caso prove ter aquele índice, o sindicato recebe do Ministério do Trabalho a certificação que o habilita a existir. Mas o índice deve ser mantido ao longo do tempo - de tal modo que nada impede que o sindicato acabe perdendo a representação.

No entanto, pode uma central, uma confederação ou uma federação criar diretamente um sindicato, mesmo sem aqueles $20 \%$. Do mesmo modo, pode filiar em seus quadros um sindicato já existente, sem que este tenha cumprido o requisito. É a chamada "representação derivada", diferente da "representação comprovada", e sobre a qual falaremos adiante.

É importante notar que as centrais integrarão o sistema, o que não acontece hoje, pelo menos na teoria. Mas, para isso, também elas terão de ser representativas, o que significa atender a três desses quatro requisitos, verbis:

“1. A Central Sindical deverá contar com Sindicatos reconhecidos em pelo menos 18 (dezoito) Estados da Federação, contemplando as cinco regiões do País;

2. Dentre os 18 (dezoito) Estados da Federação com representação da Central Sindical, em pelo 9 (nove) a soma dos trabalhadores empregados sindicalizados nos Sindicatos pertencentes à Central Sindical deve ser igual ou superior a 
$15 \%$ da soma dos trabalhadores empregados em cada um desses Estados;

3. A soma dos trabalhadores empregados sindicalizados nos Sindicatos pertencentes à Central Sindical deve ser igual ou superior a $22 \%$ da soma dos trabalhadores empregados nas bases de representação de seus Sindicatos;

4. Em pelo menos 7 (sete) setores econômicos, previstos na legislação, a soma dos trabalhadores empregados sindicalizados nos Sindicatos pertencentes à Central Sindical deve ser igual ou superior a $15 \%$ da soma dos trabalhadores empregados em cada um desses setores econômicos em âmbito nacional".

Atualmente, segundo participantes da bancada do Governo, apenas a CUT seria capaz de atender a essas exigências. Mas na própria CUT há quem diga que a Força Sindical também as atenderia. De todo modo, como haverá um prazo de transição, é provável que pelo menos aquelas duas centrais permaneçam. Aliás, se isso não acontecer, é ainda mais provável que as regras sejam mudadas.

As confederações serão organizadas não por ramo, mas por setor de atividade. Curiosamente, a diferença entre ramo e setor foi deixada para o Poder Executivo. Ou seja: embora se tenha feito a distinção, não se sabe exatamente do que se trata. Mas a idéia geral é a de que o setor seja algo mais global.

Arriscando um exemplo, toda a indústria seria um setor, e a indústria metalúrgica, um ramo de atividade. Mas a matéria ainda está em aberto. Como ponto de partida para as discussões, fixou-se um número de 14 setores na economia brasileira.

Do mesmo modo que os sindicatos, as confederações tanto poderão se constituir com independência como se filiar às centrais. $\mathrm{Na}$ última hipótese, sua representação também será “derivada”. Não sendo assim, terão de obedecer às seguintes regras, in verbis:

"1. A Confederação Sindical deverá contar com Sindicatos reconhecidos em pelo menos 18 (dezoito) Estados da Federação, contemplando as 5 (cinco) regiões do País;

2. Dentre os 18 (dezoito) Estados da Federação com representação da Confederação, em pelo menos 9 (nove) a soma dos trabalhadores empregados sindicalizados nos Sindicatos pertencentes à Confederação deve ser igual ou superior a $15 \%$ da soma dos trabalhadores empregados em cada um desses Estados;

3. A soma dos trabalhadores empregados sindicalizados nos sindicatos pertencentes à Confederação deve ser igual ou superior a $22 \%$ da soma dos trabalhadores da base de representação de seus Sindicatos”.

Quanto às federações, serão organizadas por ramo de atividade e também poderão ter representação derivada. Não acontecendo isso, estarão sujeitas aos seguintes critérios:

"1. A soma dos trabalhadores empregados sindicalizados nos Sindicatos pertencentes à Federação deve ser igual ou superior a $22 \%$ da soma dos trabalhadores da base de representação de seus Sindicatos;

2. A soma dos trabalhadores empregados sindicalizados nos Sindicatos pertencentes à Federação deve ser igual ou superior a $15 \%$ da soma dos trabalhadores empregados no ramo de atividade econômica da base de representação da Federação". 12

As centrais podem criar (ou manter) confederações, federações e sindicatos. As confederações podem criar (ou manter) federações e sindicatos. E as federações podem criar (ou manter) sindicatos.

12 Os critérios acima transcritos foram extraídos do Relatório da Comissão de Sistematização do FNT, Brasília, março de 2004. 
Em todas essas hipóteses, como vimos, as entidades criadas ou mantidas não precisam obedecer àqueles requisitos. A representação será derivada. Mas para que isso seja possível, a entidade que criar outra (de nível inferior) terá de se manter representativa (a menos que ela própria retire a sua representatividade de outra superior).

Para entender melhor o mecanismo, imaginemos que uma central esteja exatamente no limite dos índices de representatividade, sem nenhuma sobra. Nesse caso, não poderá transformar em sindicato uma associação sem representatividade. Suponhamos, agora, que ela esteja apenas um pouco acima daquele limite. Nessa hipótese, pode ser que consiga criar o sindicato, mas ela própria pode se tornar não representativa. É que os números relativos ao sindicato criado serão naturalmente computados quando for calculada a representatividade da própria central. Assim, a proporção dos empregados sindicalizados, em relação aos não sindicalizados, será menor.

Desse modo, para que uma central crie ou mantenha uma entidade sindical pouco representativa, é preciso que ela própria tenha gordura suficiente - o que a levará a considerações estratégicas, na base da relação custo/benefício. Também por isso, pode acontecer que uma central resolva extinguir a entidade criada. Aliás, conforme o caso, a sua própria sobrevivência poderá depender disso.

Note-se que os critérios para aferir a representatividade das entidades sindicais só passarão a vigorar depois de um período de transição - que deve se estender por 36 meses, mas pode ser prorrogado por outros 24 . Nesse período, as exigências serão menores.

Outro ponto importante: os sindicatos com monopólio de representação têm de ter representatividade "comprovada". Não podem ser "derivados".

Por fim, haverá organização nos locais de trabalho (OLT). Como não houve acordo sobre o seu funcionamento e constituição, o tema foi remetido à Comissão de Sistematização. Mas é quase certo que o sindicato estará presente.

\subsection{A negociação coletiva}

O modelo proposto lembra a "negociação articulada" italiana. Poderá haver um contrato coletivo em nível maior (até nacional), a partir do qual serão celebrados convenções e acordos. Em princípio, as regras mais importantes, e também as mais genéricas, seriam fixadas em níveis maiores, e em seguida especificadas ou completadas em níveis menores. Mutatis mutandi, seria algo parecido com a relação que existe entre a Constituição, a lei ordinária e o decreto que a regulamenta, embora nem sempre com a mesma rigidez.

Quando existirem, os instrumentos normativos de nível superior "deverão indicar as cláusulas que não podem ser modificadas em nível(eis) inferior(es), observadas as peculiaridades de cada âmbito de representação e de empresas ou unidades produtivas". ${ }^{13}$ Naturalmente, na prática, essa regra tanto poderá servir para preservar conquistas como para espalhar precariedades.

Havendo mais de uma entidade sindical na mesma base, seja de empregados, seja de patrões, cada uma delas terá representantes na bancada de negociação, em número proporcional ao dos trabalhadores filiados.

\footnotetext{
${ }^{13}$ Relatório da Comissão de Sistematização, op.
} cit., p. 34. 
A bancada deverá estabelecer como será tomada a decisão final a respeito da assinatura (ou não) do convênio coletivo.

A negociação coletiva será obrigatória embora as partes, naturalmente, possam não chegar a um consenso. Caso uma das entidades representativas se recuse a negociar, a titularidade da negociação pode ser conferida a outra. ${ }^{14}$ Na mesma hipótese, os "responsáveis diretos" estarão sujeitos a "multas e penas estabelecidas na lei". Além disso, se a recusa for reiterada, o sindicato pode perder suas "prerrogativas e atribuições". ${ }^{15}$

Se não houver entidade sindical disposta a negociar, os trabalhadores podem deliberar diretamente, o que a atual CF não permite. Excetuando-se essa hipótese, a negociação coletiva só poderá ser realizada, do lado dos trabalhadores, por entidades sindicais que os representem. Já do lado patronal, poderá ser firmada por empresas ou "unidades produtivas".

O instrumento coletivo terá plena eficácia jurídica, como já acontece hoje. E está garantido o direito à informação. $\mathrm{O}$ prazo de vigência, salvo ajuste em contrário, será de até três anos, ao fim dos quais haverá prorrogação automática por 90 dias - prazo que também poderá ser prorrogado por acordo. Se persistir o impasse, as partes poderão eleger árbitro. $\mathrm{Na}$ impossibilidade disso, "o conflito será submetido à arbitragem pública por meio da Justiça do Trabalho".

Embora o documento do Fórum não o diga claramente, a Justiça do Trabalho só

${ }^{14}$ Não está esclarecido qual seria essa outra, já que todas as entidades sindicais da mesma base participam, como vimos, da bancada de negociação.

${ }^{15}$ Idem, ibidem. atuaria na impossibilidade de renovação de instrumentos normativos. Os "conflitos novos" serão "abertos", ou seja, podem se estender indefinidamente.

Quanto ao conteúdo da negociação coletiva, o documento da Comissão de Sistematização diz que

"O novo marco normativo da negociação coletiva deve considerar a realidade dos setores econômicos, das empresas ou das unidades produtivas, e as necessidades dos trabalhadores, ressalvados os direitos definidos em lei como inegociáveis (...)"

Note-se que os "direitos definidos em lei" não são, necessariamente, os que a lei hoje define como inegociáveis. Ao contrário. Nas entrelinhas dos consensos firmados, o que se percebe é a tendência de se limitar as normas de ordem pública a um "mínimo" - que será certamente menor do que o atual.

Haverá negociação coletiva no setor público, mas regulamentada à parte. Para isso, o Fórum fixou o prazo de 120 dias, a partir da entrega ao Congresso das conclusões a respeito da reforma sindical.

\subsection{Proteção contra atos anti-sindicais}

A proposta de reforma considera nulo todo ato tendente a:

“a) subordinar o emprego de um trabalhador à filiação ou não a uma entidade sindical, ou ainda, ao seu desligamento;

b) despedir ou discriminar no exercício regular das funções um trabalhador devido à sua filiação, atividade sindical ou participação em greve",16

A solução natural, em caso de despedida discriminatória, seria a reintegração no

\footnotetext{
${ }^{16}$ Relatório..., op. cit., p. 34-35.
} 
emprego. É o que se conclui não só pelo caráter de nulidade do ato, como porque, segundo o mesmo documento,

"a futura legislação deve prever expressamente a possibilidade de reversão judicial do comportamento lesivo mediante um procedimento ágil e simplificado" (grifos nossos)

Será também proibido conceder "tratamentos econômicos de favorecimento, com caráter discriminatório, decorrentes da filiação ou da atividade sindical”. A pena será de multa.

\subsection{A composição dos conflitos}

Esquecendo-se da hipótese de "arbitragem compulsória" pela Justiça do Trabalho, afirma o Relatório que as formas de solução dos conflitos coletivos serão "sempre" voluntárias. Os serviços e atividades essenciais terão disciplina específica, como já acontece.

Havendo greve, os meios de solução deverão ser a conciliação, a mediação e a arbitragem. A Justiça do Trabalho poderá julgar os conflitos de natureza jurídica. Quanto aos de natureza econômica, só poderá atuar como árbitro e mediante o requerimento de ambas as partes (salvo na hipótese acima lembrada).

Na esfera individual, o novo sistema também como já acontece hoje - preverá formas de composição extrajudicial, mas sempre com assistência sindical.

\subsection{A substituição processual}

A substituição processual será ainda objeto de regulamentação, a cargo da Comissão de Sistematização. Havendo impasse, prevalecerá a seguinte proposta:
"É atribuição das entidades sindicais de trabalhadores e de empregadores a defesa dos direitos e interesses individuais e coletivos dos trabalhadores e empregadores, inclusive em questões judiciais e administrativas, conforme a lei”.

Nessa hipótese, como se vê, a substituição poderia ser ampla. Mas também correria o risco de ser restringida pela lei. Note-se ainda que a proposta nada diz sobre a possibilidade de renúncia ou desistência por parte dos trabalhadores beneficiados.

\subsection{O direito de greve}

A proposta é manter o texto da Constituição:

"É assegurado o direito de greve, competindo aos trabalhadores decidir a oportunidade de exercê-lo e sobre os interesses que devam por meio dele defender".

O Relatório diz que não deve haver diferença entre trabalhadores e líderes da greve. E proíbe o julgamento da greve pelo Poder Judiciário. Além disso, suprime o parágrafo único do art. 15 da Lei n. ${ }^{\circ} 7.783$, que determina a abertura de inquérito, por requisição do MP, e posterior ação penal, quando houver indício de prática de delito. Em verdade, a supressão não fará qualquer diferença, a menos que se altere o Código de Processo Penal...

$\mathrm{O}$ aviso-prévio para a greve será de 72 horas, salvo no caso de não pagamento de salários e/ou de descumprimento de convênio coletivo. O quorum para deliberar a greve será o previsto nos estatutos. E há uma proibição geral de atos discriminatórios durante o movimento.

No mais, não há novidades importantes. A própria definição de greve é a da lei atual:

“...suspensão coletiva temporária, total ou parcial, da prestação de serviços a empregador". 


\subsection{Contribuições sindicais}

A contribuição sindical obrigatória será extinta gradualmente, no prazo de três anos.

Tal como já acontece, as entidades sindicais de trabalhadores poderão cobrar mensalidades de seus associados. A empresa deverá fazer o desconto em folha de pagamento, sob pena de responder pela prática de ato anti-sindical.

Haverá ainda uma "contribuição de negociação coletiva", a ser paga por todos os trabalhadores, filiados ou não, que se beneficiarem do instrumento normativo. O valor será aprovado em assembléia, não podendo ultrapassar $1 \%$ da remuneração líquida recebida no ano anterior.

O pagamento dessa contribuição será feito em três parcelas mensais, no mínimo, a partir de abril. E servirá para custear não só o sindicato e as entidades de grau superior a ele vinculadas, mas um Fundo Solidário de Promoção Sindical, sobre o qual falaremos adiante. Caso a entidade não esteja filiada a qualquer outra de nível superior, a contribuição irá toda para o Fundo.

Se mais de uma entidade participar da negociação, o repasse do dinheiro será feito proporcionalmente à taxa de sindicalização de cada uma. Mas só as entidades sindicais "que comprovarem sua representatividade" a receberão. O direito de oposição só poderá ser exercido nas assembléias destinadas a fixar o valor da contribuição.

5.8 O Conselho Nacional de Relações de Trabalho, as Câmaras Bipartites e o Fundo Solidário de Promoção Sindical

Haverá um Conselho Nacional de Relações de Trabalho, composto de cinco titulares e cinco suplentes: (a) de trabalhadores indicados pelas centrais sindicais; (b) de empregadores indicados pelas confederações; e (c) do Governo, indicados pelo Ministério do Trabalho e Emprego. Há regras específicas para um período de transição.

Caberá a esse Conselho, dentre outras coisas, propor diretrizes de políticas públicas e avaliar programas e ações oficiais na esfera das relações do trabalho; subsidiar pareceres sobre projetos legislativos; fixar critérios para utilização dos recursos do Fundo Solidário de Promoção Sindical; propor critérios e dirimir dúvidas sobre enquadramento sindical; examinar em segundo grau as contestações e indeferimentos de pedidos de registro sindical; definir os setores econômicos e ramos de atividade que poderão obter tratamento específico.

Será o Conselho, também, quem irá propor a definição dos setores econômicos e ramos de atividade, para fins de organização sindical e negociação coletiva, assim como os critérios de enquadramento. Irá também propor as normas estatutárias dos sindicatos que aderirem à exclusividade de representação.

Já as Câmaras Bipartites serão duas, cada qual formada por cinco titulares e cinco suplentes. Uma delas terá apenas representantes dos trabalhadores e do Governo; a outra, dos empresários e do Governo. Caberá a essas Câmaras examinar em primeira instância as contestações e indeferimentos dos pedidos de registro sindical; administrar os recursos do Fundo Solidário; e conciliar e mediar conflitos de representação de entidades sindicais de trabalhadores e empregadores, respectivamente.

\section{O Fundo Solidário de Promoção Sindical} servirá para custear as atividades do Conselho, assim como para realizar estudos, pesquisas e programas de valorização do movimento 
sindical e ligados à saúde, ao meio ambiente e às relações de trabalho.

\subsection{Algumas conclusões sobre o novo sistema proposto}

A reforma radicaliza e institucionaliza uma tendência de centralização, que já se anunciava, na prática, no movimento sindical brasileiro. Nesse novo quadro, os principais atores não serão os sindicatos, mas os órgãos de cúpula, seja agindo diretamente, seja por meio deles. O mais provável é que a maioria dos sindicatos vá depender da "representação derivada". Mas como não haverá tanta gordura a perder, mesmo o número dos "derivados" tende a cair. A centralidade do sindicalismo estará realmente com as centrais.

Ora, um sistema como esse pode oferecer algumas vantagens, mas também traz sérios riscos.

De um lado, pode-se dizer que as centrais têm mais visibilidade, e por isso sempre sofrem um controle maior da sociedade-o que sempre é bom. Além disso, tendem a politizar as reivindicações; e, mais fortalecidas, podem ter algum sucesso na tentativa de reunificar o movimento operário.

Em contrapartida, a falta de um efetivo controle das bases pode levar a um peleguismo de cúpula. Além disso, ou talvez por isso, há o risco de que os governos, presentes ou futuros, utilizem as centrais para viabilizar e legitimar o processo de precarização. Até a proximidade dos dirigentes com o poder deve aproximá-los também das estratégias do poder - que tendem a se envolver de forma crescente com os interesses do capital.

E isso nos leva ao ponto-chave da reforma: a negociação coletiva. Como dizíamos, na medida em que os patamares legais diminuírem, o sindicato irá ganhando um papel maior, em termos quantitativos, mas menor, em termos qualitativos, no campo da negociação. Já não será, sequer, um sindicato de resultados. $\mathrm{E}-$ lembrando um pouco o que acontece na "representação derivada" - estará legitimando o sistema à custa de seu próprio sangue, vale dizer, de sua própria legitimidade.

Outro ponto importante diz respeito à sobrevivência do monopólio de representação para os sindicatos existentes até às vésperas da nova lei. Embora a proposta fale em opção, é pouco provável que as assembléias escolham a pluralidade. Será mais ou menos como a antiga "opção" pelo FGTS.

Por fim, o sindicato continuará como uma ilha. Não abrirá as suas portas para as multidões crescentes de trabalhadores sem vínculo de emprego.

\section{A REFORMA SINDICAL VISTA PELOS JUÍZES}

Para a ANAMATRA, uma reforma que resgate o papel histórico do sindicato; valorize a positivamente a negociação coletiva; preserve os direitos dos empregados; e estenda o seu campo de proteção a todos os trabalhadores, passa pelos seguintes pontos, justificados sinteticamente:

\subsection{Estrutura sindical}

\section{Garantia de emprego para todos.}

A proteção contra a despedida arbitrária para o conjunto dos trabalhadores é pressuposto de um sindicalismo forte, que possa atuar inclusive na defesa dos que estão fora do mercado de trabalho. 
2. Estabilidade provisória do dirigente sindical.

Sem ela, também não pode haver um sindicato forte.

3. Reconhecimento das centrais como entidades sindicais, mas num contexto de plena democracia, que assegure o seu controle permanente pelos trabalhadores.

Tão importante quanto legalizar as centrais como entidades sindicais é torná-las efetivamente democráticas, o que implica uma interação permanente de cúpulas e bases.

4. Fixação de critérios legais para aferir permanentemente a legitimidade sindical, em todos os níveis.

Tão importante quanto garantir a legitimidade sindical é evitar que as entidades de grau superior manipulem politicamente o poder de eleger os sindicatos mais representativos.

5. Autonomia e independência financeira dos sindicatos em todos os níveis.

Exatamente para garantir a plena democracia sindical, é importante que os sindicatos tenham autonomia em termos formais e reais. $\mathrm{O}$ fato de se filiarem a uma central não deve torná-los dependentes dela.

6. Legitimação sindical ampla para as ações para defesa dos direitos e interesses coletivos, difusos e individuais homogêneos.

Para pôr fim a discussões, é preciso deixar claro que os sindicatos têm essa prerrogativa - sem possibilidade de renúncia de direitos individuais.

7. Organização por ramo de atividade empresarial preponderante, com base territorial mínima de um Município.

Para fazer frente à fragmentação da classe trabalhadora, é recomendável, mas não suficiente, a organização por ramo de atividade. O ideal será que este critério seja acoplado ao de uma base territorial mínima. E mais: é preciso que o sindicato possa também se articular com outros movimentos sociais, abrindo-se para trabalhadores sem emprego, subempregados ou de algum outro modo excluídos.

8. Inserção dos trabalhadores terceirizados no sindicato constituído pelo ramo de atividade empresarial preponderante do tomador do serviço, sem prejuizo da restrição ao trabalho terceirizado - que se considera fundamental implementar-se na futura reforma trabalhista.

Ainda com o objetivo de recompor o fragmentado, os trabalhadores terceirizados devem ser explicitamente incluídos entre os empregados da empresa tomadora, para fins de organização sindical - o que resultará na sua equiparação também em termos de conquistas. Mas isso não significa abrir mão da luta maior no sentido de restringir o mais possível essa forma de exploração do trabalho alheio.

9. Possibilidade de filiação sindical de trabalhadores que não se incluam em outro ramo de atividade.

O sindicato deve abrigar não só empregados e terceirizados, mas também aqueles que estão fora do mercado formal como desempregados e excluídos em geral. Desse modo, estará também reconstruindo em outras bases - a solidariedade em crise.

10. Fim da unicidade sindical, com vedação à possibilidade de declaração de monopólio de representação pela lei ou pelo próprio sindicato.

O princípio da unicidade sindical deve ser substituído pela prática da unidade sindical, que implica um ato de escolha, não de imposição. Em outras palavras, serão os 
sindicatos a optar pela estratégia de se reduzirem a poucos ou mesmo a um só. Mesmo os sindicatos que atualmente detêm monopólio de representação terão de se ajustar à nova regra. Apenas para negociar é que se exigirão índices de representatividade.

11. Proteção contra atos anti-sindicais.

Atos anti-sindicais devem ser reprimidos duramente, inclusive com a sua tipificação penal. Dentre esses atos devem ser incluídos os praticados por dirigentes sindicais que traiam o mandato que lhes foi confiado. Do mesmo modo, a despedida do empregado pelo simples fato de ser sindicalizado ou militante sindical.

\subsection{Representação dos trabalhadores na empresa}

1. Organização nos locais de trabalho, aproveitando-se a estrutura da CIPA, com a participação do sindicato, e como instrumento de fiscalização e de co-gestão, participação e informação dos trabalhadores na empresa, vedadas a transação e a renúncia de direitos, e garantida a estabilidade provisória a todos os seus membros.

A organização nos locais de trabalho deverá introduzir um início de democracia na empresa, partilhando o poder diretivo e aumentando a efetividade dos direitos individuais. Para garantia de sua independência, terá a participação do sindicato, o que não significa que será fechada a não sindicalizados. Exatamente porque uma de suas funções básicas será a de dar maior eficácia social aos direitos, não poderá desempenhar o papel inverso, homologando renúncias e transações. Naturalmente, todos os seus membros terão estabilidade provisória.

\subsection{Negociação coletiva}

1. Obrigatoriedade da participação sindical obreira na negociação coletiva trabalhista.

Tal como já ocorre hoje, por força da Constituição Federal, será obrigatória a presença de uma entidade sindical de trabalhadores na negociação coletiva - para garantir não só o fortalecimento do sindicato, como o conteúdo positivo da própria negociação.

2. Sujeito da negociação coletiva será o sindicato que tiver a maior representatividade, nos termos da lei, a qual preverá critérios democráticos de aferição contínua da representatividade.

A idéia é conjugar pluralismo com representatividade. Assim, só o sindicato mais representativo poderá negociar. Mas os critérios de aferição devem ser efetivamente democráticos, o que implica a possibilidade permanente de alternância dos atores na posição de negociador.

3. Efeito erga omnes dos instrumentos coletivos negociados.

É um critério que deve ser preservado, especialmente hoje, pois garante o princípio constitucional da isonomia, opõe-se à segmentação crescente dos trabalhadores e reduz a concorrência entre eles.

4. Utilização dos instrumentos coletivos negociados como forma de melhoria das condições de trabalho e não como instrumentos de precarização.

O convênio coletivo deve ser visto, conceitualmente, como um mecanismo de crescente redução das disparidades entre os atores sociais e não como uma estratégia para legitimar a perda de conquistas históricas dos trabalhadores. $\mathrm{O}$ instrumento coletivo que 
não sirva a esse fim não é o que pretende ser, e por isso não terá validade legal.

5. Prevalência do princípio da norma mais favorável em sede de negociação coletiva trabalhista.

O princípio da norma favorável decorre de um princípio maior, o da proteção, que é a própria razão de ser do Direito do Trabalho e o resultado de lutas históricas dos trabalhadores. Por isso, deve ser não só preservado, como explicitado.

6. Ultratividade do instrumento normativo até que outro o revogue.

Trata-se de um mecanismo que possibilita uma equivalência mais efetiva entre as partes. Permitir que cada negociação coletiva recomece do zero é também levar a próxima de zero a possibilidade de seu avanço crescente, em termos sociais.

7. Não obrigatoriedade da negociação coletiva.

Negociar ou não é ato de liberdade dos atores sociais. Forçar a negociação traz como conseqüência necessária a imposição de meios - judiciais ou não - de solução do conflito. O melhor, portanto, é a garantia da liberdade, atrelada à ultratividade.

8. Preservação dos direitos trabalhistas assegurados na Constituição da República.

Os direitos trabalhistas assegurados na Constituição - todos, e não apenas os elencados no art. $7 .^{\circ}$ - são fundamentais, e, por conseqüência, cláusulas pétreas.

9. Explicitação em lei do entendimento de que a norma constitucional permissiva de redução salarial em negociação coletiva limita-se ao salário normativo e não ao legal e contratual.

Normas restritivas de direito devem ser interpretadas também restritivamente. Desse modo, o disposto na parte final do art. $7 .^{\circ}$, inciso VI, da Constituição, deve merecer interpretação autêntica no sentido de que a sua esfera de incidência é o salário normativo e não o salário legal ou contratual. Ao mesmo tempo, deve ser rechaçada a possibilidade de sua aplicação analógica.

\subsection{Direito de greve}

\section{Extinção do dissídio de greve.}

Mais que um direito, a greve tem sido, ao longo dos tempos, o mais importante instrumento de conquista de direitos (Washington L. da Trindade). O julgamento das greves pelos tribunais, impondo o fim do movimento, dificulta e às vezes inviabiliza o seu êxito.

2. Limitação da competência da Justiça do Trabalho, por meio do juizo de primeiro grau, para as hipóteses em que houver greve em atividades essenciais e estiverem em jogo as necessidades inadiáveis da comunidade.

Apenas quando o interesse público for intenso, poderá a Justiça do Trabalho apreciar a greve, por meio do juízo de primeiro grau.

3. Aplicação e interpretação do direito de greve em conformidade com o art. $9^{\circ} \mathrm{da}$ Constituição da República, revogando-se as restrições impostas pela Lei de Greve (Lei $n .^{o} 7.783 / 89$ ).

Salvo nas hipóteses de atividades e serviços essenciais, quando faz remissão à lei ordinária, a Constituição Federal garante um direito de greve amplo. No entanto, esse direito vai sendo restringido, seja pelo legislador, seja pela interpretação dos tribunais. Para agravar esse quadro, a realização de greves vai-se tornando cada vez mais difícil. Já não há um equilíbrio de forças, mesmo relativo, entre os atores sociais. Assim, não só aquelas inconstitucionalidades devem ser corrigidas, 
como o próprio conceito de greve deve ser ampliado, de modo a abranger outras formas de ruptura com o cotidiano da prestação de serviços, desde que razoáveis e não abusivas.

4. Vedação da contratação de trabalhadores durante a greve, inclusive terceirizados.

A fim de aumentar a efetividade do direito de greve, deve-se impedir a contratação de quaisquer substitutos para os grevistas, sejam eles ou não empregados do tomador de serviços.

\subsection{Dissídio Coletivo}

Fim do poder normativo, condicionado à aplicação concreta das demais propostas.

Embora também tenha servido, aqui e ali, para estender a grupos mais frágeis as conquistas realizadas por categorias mais fortes, o poder normativo acaba inibindo as lutas sindicais, permitindo a sobrevivência de sindicatos pelegos e dificultando a emergência de lideranças responsáveis e conscientes de seu papel. No entanto, e exatamente em razão de seus aspectos positivos, a comissão de juízes que debateu o problema concluiu que o poder normativo só deve ser extinto na medida em que se criarem mecanismos que o compensem e superem - tais como os alinhados nos itens anteriores.

\section{EM SÍNTESE}

Como se vê, há pontos de convergência entre as propostas do Fórum e as dos juízes. Mas há também fortes divergências, como, por exemplo, em relação à negociação coletiva.

É evidente que as propostas dos juízes não foram resultado de um confronto. Não havia interesses conflitantes. Aliás, nem interesses havia, senão os de tentar contribuir, minimamente, para a reconstrução do País.
Assim, e ao contrário do que aconteceu no Fórum, os juízes não precisaram ceder. Não negociaram. Daí por que, possivelmente, várias de suas propostas são as que os trabalhadores gostariam de ter aprovado e não conseguiram.

Por outro lado, num contexto de preservação do sistema capitalista, é evidente que uma solução de consenso, em princípio, é sempre bem-vinda. Dá força ao negociado, facilita o processo legislativo, ensina o diálogo e a tolerância e previne futuros conflitos.

No entanto, e tal como acontece com a palavra "trabalho", um consenso pode conter dentro de si o positivo e o negativo. $\mathrm{Ou}$, como dizem os chineses, o yin e o yang.

Para que o positivo supere o negativo, um consenso tem de ser realmente democrático o que implica reunir todos os atores da peça. E é preciso que haja um certo equilíbrio entre os envolvidos. Sem isso, uma negociação pode esconder um ato de autoridade.

No caso do Fórum, não nos parece que tenha havido uma situação de equilíbrio. A própria ausência efetiva de procuradores, advogados e juízes no debate impediu que se acrescentassem alguns pesos na balança. Aliás, também ficaram de fora - como sempre - os excluídos.

Por isso, o resultado não foi dos melhores e talvez venha a ser pior do que parece. Apesar de alguns avanços pontuais, o Fórum pode ter preparado o terreno para a construção de um sindicato e uma negociação coletiva em contradição com a história, o papel e o próprio conceito de cada qual. Fica, porém, a esperança de que algumas reviravoltas aconteçam, ou a de que - quem sabe? - o futuro desminta essas nossas previsões. 